\title{
The effect of oviductal deleted in malignant brain tumor 1 over porcine sperm is mediated by a signal transduction pathway that involves pro-AKAP4 phosphorylation
}

\author{
Juan Manuel Teijeiro and Patricia Estela Marini \\ Facultad de Ciencias Bioquímicas y Farmacéuticas, Instituto de Biología Molecular y Celular de Rosario (IBR- \\ CONICET) y Área Biología, UNR, Suipacha 590, S2002LRK Rosario, Argentina \\ Correspondence should be addressed to P E Marini; Email: marini@ibr.gov.ar \\ $\mathrm{P}$ E Marini is a Member of the research career (CIC-UNR)
}

\begin{abstract}
The interaction between sperm and oviduct results in the selection of sperm with certain qualities. Porcine oviductal deleted in malignant brain tumor 1, DMBT1 (previously called sperm-binding glycoprotein, SBG), has been proposed to be implicated in sperm selection through acrosome alteration and suppression of motility of a subpopulation of sperm that have begun capacitation prematurely. It produces in vitro acrosome alteration and decrease of motility of boar sperm, concomitant with tyrosine phosphorylation of a $97 \mathrm{kDa}$ sperm protein (p97). We hypothesized that the phosphorylation of p97 may be a link between DMBT1 sensing by a subpopulation of boar sperm and its biological effect. In this work, p97 was identified by mass spectrometry and immunoprecipitation as a porcine homologue of AKAP4. Pro-AKAP4 was localized by immunofluorescence and subcellular fractionation to the periacrosomal membranes and was shown to be tyrosine phosphorylated by DMBT1 regardless of the presence of calcium or bicarbonate, and of cAMP analogs, protein kinase $A$ inhibitors, or a protein kinase $C$ inductor. A processed $\sim 80 \mathrm{kDa}$ form of AKAP4 was also detected at the tail of boar sperm, which was not tyrosine phosphorylated by DMBT1 under the conditions tested. Immunohistochemistry of testis showed presence of AKAP4 in boar sperm precursor cells. The evidence presented here supports the involvement of AKAP4 in the formation of the fibrous sheath on boar precursor sperm cells and implicates the phosphorylation of pro-AKAP4 as an early step in the signal transduction pathway gated by DMBT1 that leads to sperm selection through acrosome alteration.
\end{abstract}

Reproduction (2012) 143 773-785

\section{Introduction}

The oviduct is a dynamic organ in which final gamete maturation and the first stages of embryo development take place. This organ, particularly its isthmic region, is largely responsible for sperm selection. When boar spermatozoa enter the oviduct, two major subpopulations are formed. Most sperm, which are considered to be selected for high quality (for review, see Talevi \& Gualtieri (2010)), are found at the bottom of the crypts of the oviductal folds bound to epithelial cells forming a reservoir. A minority of sperm, however, are seen in situ at the lumen of the oviduct showing membrane alteration and poor vitality (Mburu et al. 1996, Tienthai et al. 2004). As the binding and detachment from the oviduct in the formation and release from the sperm reservoir provide sperm selection, the degeneration of a subpopulation of sperm at the lumen of the oviduct may be considered a different kind of sperm selection, negative selection. Efforts are actually being taken to understand the mechanism responsible for the latter, which may be related to the control of polyspermy. In this regard, a role for oviductal fluid at the follicular phase has been suggested (Coy et al. 2010). The oviductal glycoprotein deleted in malignant brain tumor 1 (DMBT1), previously called sperm-binding glycoprotein (SBG; Teijeiro et al. 2012), has also been considered partially responsible for this selection process (Teijeiro et al. 2008, 2011). This protein localizes to the apical surface of cells at the lumen of the porcine oviduct (Perez et al. 2006) in coincidence with the localization of damaged sperm reported in vivo (Mburu et al. 1996, 1997) and produces in vitro acrosome alteration of capacitating sperm (Teijeiro et al. 2008). It was first isolated from the oviduct based on its ability to bind to boar sperm periacrosomal membranes (Marini \& Cabada 2003) and produces not only alteration of pig sperm acrosome integrity but also another biological effect, suppression of motility, as well as tyrosine 
phosphorylation of a $97 \mathrm{kDa}$ sperm protein (p97; Teijeiro et al. 2008, 2011). The reduction of sperm motility in the oviduct (Overstreet \& Cooper 1975, Satake et al. 2006) and the existence of damaged sperm at its lumen have been known for long; however, only recently, the study of the mechanisms involved in the oviductal epitheliumsperm signaling dialogue, related to these phenomena, has began to be unraveled.

Previous data suggest a role for DMBT1 in sperm selection (Teijeiro et al. 2008), which may be a part of the mechanism for the control of polyspermy in vivo (Teijeiro et al. 2011). We propose that a subpopulation of sperm that are present in the oviduct and have begun capacitation suffer acrosomal alteration mediated by DMBT1, constituting a mechanism by means of which negatively selected spermatozoa would be prevented from fertilizing oocytes (Teijeiro et al. 2011). As a small subpopulation of sperm is refractive to DMBT1 damaging action (Teijeiro et al. 2011), these would be able to progress to the ampulla, capacitate in the vicinity of the egg as suggested by Hunter (2002) and would be capable of fertilizing. In order to begin studying the signal transduction pathway that links DMBT1 to acrosome alteration and motility suppression, the objective of this work is to identify p97 and analyze the possible involvement of known signal transduction effectors on its mechanism of action.

\section{Results}

\section{Identification of $p 97$ as A-kinase anchor protein by mass spectrometry}

In order to identify the key protein of DMBT1-produced transduction pathway, p97, sperm were treated with DMBT1 as described in the Materials and Methods section and the phosphorylated protein of interest separated by electrophoresis and used for sequence analysis by LC/MS-MS. The report of mass spectrometry analysis, shown in Table 1, indicated that A-kinase anchor protein 4 (AKAP4) was the most abundant protein in the sample (for more information, see http://www. prottech.com), and it was chosen for further analysis. Also, molecular mass consideration promoted discarding those proteins with molecular masses different from $97 \mathrm{kDa}$. The 32 peptides contained in AKAP4 (in bold in Fig. 1) showed identity with the reported sequence for canine AKAP4 (Fig. 1). As porcine AKAP4 has not been previously reported as such, we searched for protein sequence homology in databases, finding coincidence with the translation product of a pig testicular expressed sequence tag (EST; PDUts2093G01, dbEST $\mathrm{Id}: 26680940)$. The deduced protein sequence of this EST covered 796 of the 848 amino acids (93\%) reported for canine AKAP4, with only 74 substitutions. The EST did not include the codifying sequence for the 51 amino acids amino-terminal end of canine AKAP4 (Fig. 1).
Table 1 LC-MS/MS analysis of $97 \mathrm{kDa}$ phosphorylated boar sperm protein. The corresponding $97 \mathrm{kDa}$ phosphorylated protein band was excised from SDS-PAGE and submitted for protein identification by LC-MS/MS. The number of peptides obtained by LC-MS/MS analysis and mass of its corresponding protein is indicated.

\begin{tabular}{|c|c|c|}
\hline $\begin{array}{l}\text { Protein } \\
\text { mass }\end{array}$ & $\begin{array}{c}\text { No. of } \\
\text { peptides }\end{array}$ & Sequence header \\
\hline 94482.23 & 32 & $\begin{array}{l}\text { > gi|74006942|ref|XP_851545.1| PRE- } \\
\text { DICTED: similar to A-kinase anchor } \\
\text { protein } 4 \text { isoform } 1 \text { isoform } 2 \text { (Canis } \\
\text { familiaris) }\end{array}$ \\
\hline 85316.81 & 18 & $\begin{array}{l}\text { > gi|77627998|ref|NP_001028187.2| } \\
\text { angiotensin I converting enzyme isoform } \\
1 \text { (Sus scrofa). } \\
\text { gi|77539420|dbj|BAE16967.2| testicu- } \\
\text { lar angiotensin I converting enzyme (S. } \\
\text { scrofa) }\end{array}$ \\
\hline 103338.55 & 6 & $\begin{array}{l}\text { > gi|60592784|ref|NP_001012686.1| } \\
\text { hexokinase } 1 \text { (Bos taurus) } \\
\text { gi|33332343|gb|AAQ11378.1| hexoki- } \\
\text { nase } 1 \text { (Bos taurus) }\end{array}$ \\
\hline 279025 & 6 & $\begin{array}{l}\text { > gi|55741862|ref|NP_999548.1| zonad- } \\
\text { hesin (S. scrofa) } \\
\text { gi|2499181|sp|Q28983|ZAN_PIG } \\
\text { Zonadhesin precursor } \\
\text { gi|1066466|gb|AAC48486.1| zonadhe- } \\
\text { sin }\end{array}$ \\
\hline 80631.31 & 6 & $\begin{array}{l}\text { > gi|73967876|ref|XP_861598.1| PRE- } \\
\text { DICTED: similar to outer dense fiber of } \\
\text { sperm tails } 2 \text { isoform } 4 \text { (Canis familiaris) }\end{array}$ \\
\hline
\end{tabular}

As a 15 amino acids peptide corresponding to AKAP4 amino-terminal region was identified by LC-MS/MS of pig sperm p97 (Fig. 1), we infer that porcine p97/AKAP4 (from now on pAKAP4) might contain this domain as well. Most probably, the cloned EST used for the report was not long enough as to cover the whole AKAP4 transcript.

\section{Immunological identification of p97 porcine sperm protein as AKAP4}

To confirm the mass spectrometry identification of DMBT1 mediator p97, immunological means were used. Anti-pAKAP4 antibodies were developed using a clone containing pAKAP4 EST gently provided by Dr Lee and Dr Gau (Animal Technology Institute, Taiwan). This clone was used for recombinant protein expression in Escherichia coli and antibody development in rabbit, as described in the Materials and Methods section. After confirming the specificity of the anti-pAKAP4 antibodies, they were used for western blotting of sperm extracts and comparison with already validated antimouse AKAP4 antibodies (anti-mAKAP4). As shown in Fig. 2A, both antibodies recognized two proteins of 97 and $80 \mathrm{kDa}$ on porcine sperm extract, indicating high homology between AKAP4 from both the species and supporting the specificity of the newly prepared antibodies.

To further test the affinity of the anti-AKAP4 antibodies, immunoprecipitation was performed (Fig. 2A). Proteins of 97 and $\sim 80$ kDa were precipitated 


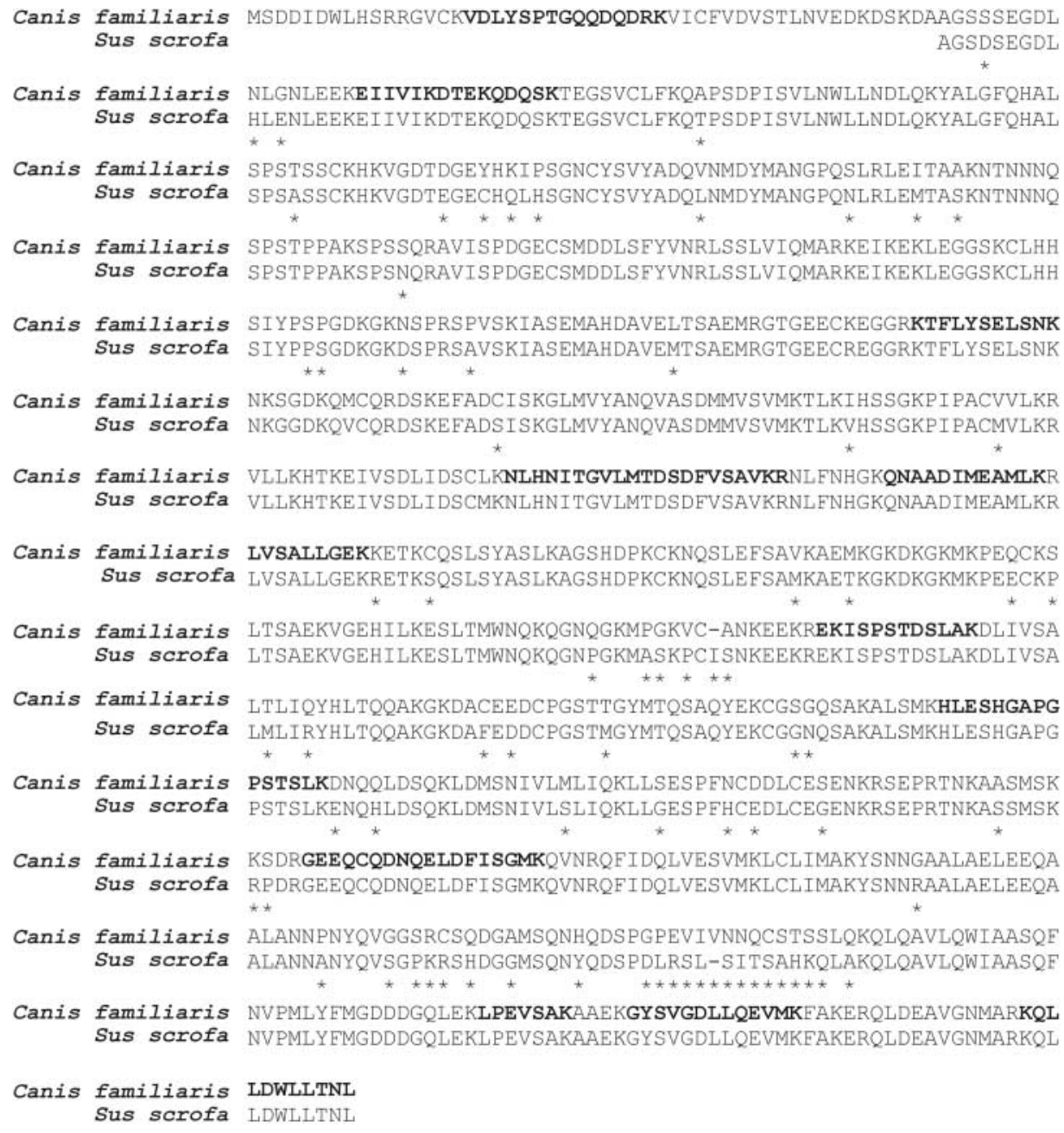

Figure 1 p97 identification by LC/MSMS as AKAP4. The sequences of canine AKAP4 (XP_851545.1) and a porcine sequence derived from a reported testicular EST (PDUts2093G01, dbEST $\mathrm{Id}: 26680940)$ are shown. Peptides obtained by $\mathrm{p} 97$ mass spectrometry analysis are shown in bold. Amino acid differences are indicated as *.
(Fig. 2A), and the $97 \mathrm{kDa}$ protein band was submitted to a sequencing facility for mass spectrometry identification. The results confirmed that the band corresponded to AKAP4.

Having validated the specificity of the immunoprecipitation with anti-pAKAP4 antibodies, experiments were developed to test whether the identified AKAP4 really corresponds to the protein that is phosphorylated by DMBT1. Sperm were incubated with and without DMBT1 and immunoprecipitation was performed with anti-pAKAP4 antibodies. Immunoprecipitated proteins were transferred to nitrocellulose membranes and first revealed with antiphosphotyrosine antibodies (anti-pY), showing a $97 \mathrm{kDa}$ band of phosphorylated protein only for DMBT1-treated sperm (Fig. 2B). Then, the membrane was stripped and revealed with anti-pAKAP4 showing a $97 \mathrm{kDa}$ protein band in both lines. Thus, pAKAP4 was detected in both the conditions but its phosphorylated form only upon DMBT1 treatment, confirming that pAKAP4 is the protein that is phosphorylated by DMBT1 treatment.

\section{Localization of AKAP4 in pig sperm and subcellular fractions}

The localization of a protein in a compartmentalized cell as in sperm may be indicative of its function. Particularly, as DMBT1 binds to the periacrosomal region of sperm (Teijeiro et al. 2008) and produces acrosomal and motility effects, localization of pAKAP4 at the tail would be an indication of possible involvement in motility decrease, while localization at the periacrosomal region could indicate its importance on acrosome alteration or an early role in signal transduction that results in any or both biological effects.

In order to localize pAKAP4, boar sperm fractionation was conducted using two different types of fractionation methods. One of the methods allows the purification of heads and tails separately, with an efficacy illustrated in Fig. 3A, T and $\mathrm{H}$. Both fractions were used for protein extraction. Another fractionation technique, described in the Materials and Methods section, allowed the separation of acrosomal content and periacrosomal 


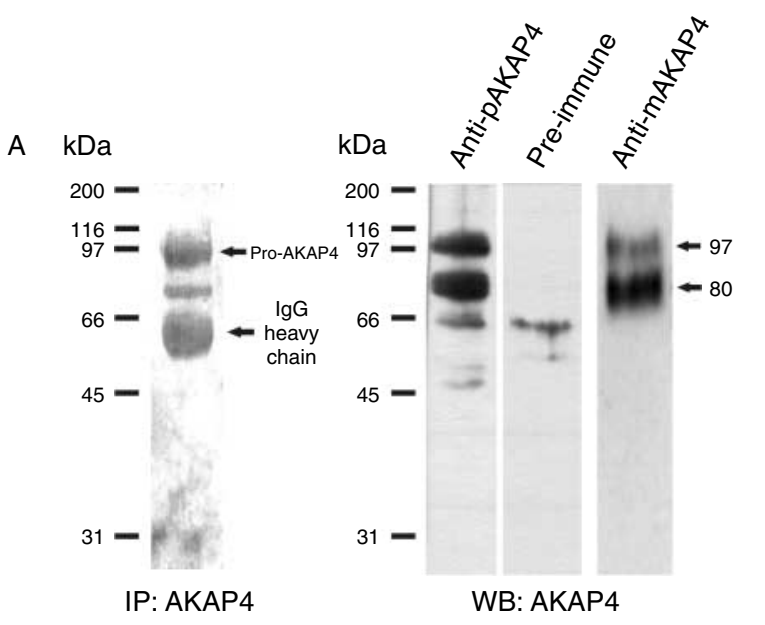

B
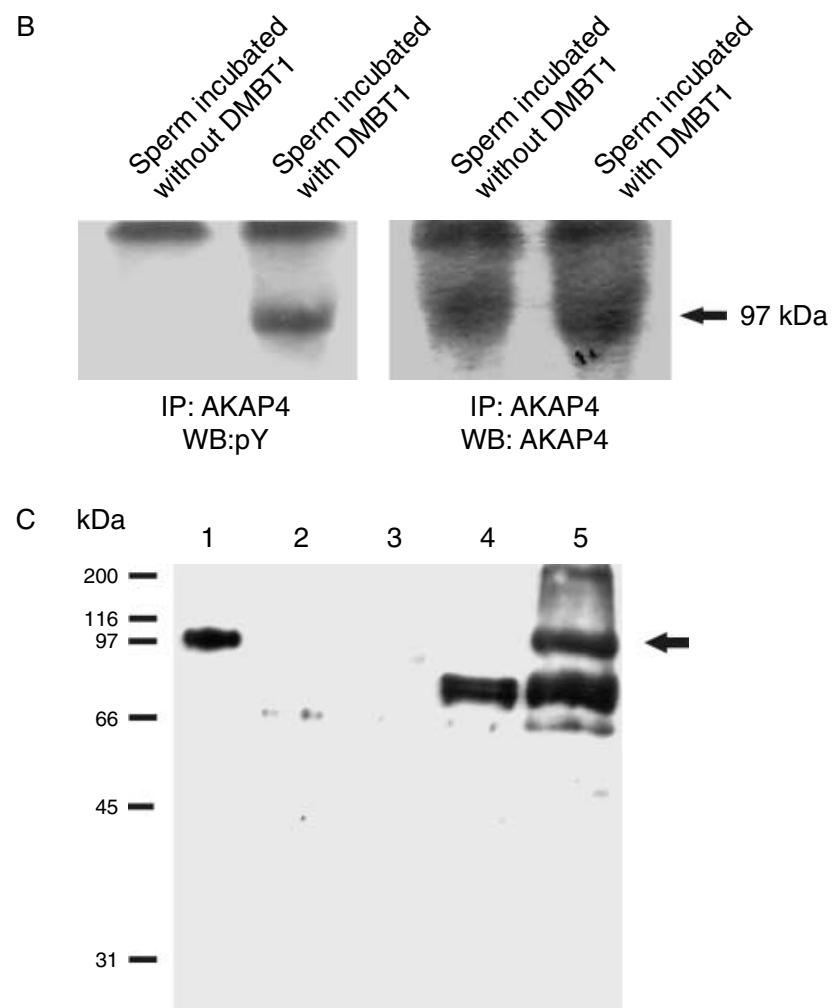

Figure 2 Identification of AKAP4 in porcine sperm fractions. (A) IP: SDS-PAGE of the immunoprecipitation product of boar sperm with anti-pAKAP4 antibodies stained with Coomassie blue. WB: western blot of whole sperm extracts $(20 \mu \mathrm{g} / \mathrm{ml})$ revealed with anti-pAKAP4, control pre-immune serum, and anti-mAKAP4 antibodies. (B) Western blot of immunoprecipitated pAKAP4 after treatment of sperm with DMBT1 and control, revealed with anti-pY (left), and anti-pAKAP4 (right). (C) Western blot revealed with anti-pAKAP4 of 1) recombinant pAKAP4 purified from $E$. coli extracts, 2) protein extract from sperm heads $(20 \mu \mathrm{g}), 3)$ protein extract from acrosomal content $(20 \mu \mathrm{g}), 4)$ protein extract from sperm tails $(20 \mu \mathrm{g})$, and 5) protein extract from periacrosomal membranes $(20 \mu \mathrm{g})$. Molecular mass standards are indicated in the left side. Arrows indicate p97, AKAP4. membranes from the rest of the sperm (illustrated in Fig. 3A, PM). The efficacy of this fractionation was confirmed by western blot with antibodies against porcine acrosin, showing that the acrosome-specific proteins (acrosin and proacrosin) are present exclusively in the acrosomal content fraction, as expected (Fig. 3B; Sostaric et al. 2005). From all the subcellular fractions mentioned, $97 \mathrm{kDa}$ pAKAP4 was detected by western blot only in periacrosomal membrane extracts (Fig. 2C, line 5). However, a protein of apparent molecular mass $\sim 80 \mathrm{kDa}$ (p80) was detected in tails (Fig. 2C, line 4) and periacrosomal membrane extracts (Fig. 2C, line 5) with anti-pAKAP4. Both bands were present in whole sperm (Fig. 2A). The lack of signal in western blot of proteins from head extracts is probably due to the loss of the periacrosomal membranes during sonication for heads and tails separation.

Anti-pAKAP4 antibodies were also used for localization of the protein in boar spermatozoa by immunocytochemistry. As shown in Fig. 4, pAKAP4-specific signal was detected at the periacrosomal region and at the principal piece of the tail of boar sperm.

\section{Localization of pAKAP4 in boar testicle}

Proteins present in mature ejaculated sperm, and especially at the periacrosomal region, may come from synthesis at immature precursor cells or from adsorption during their pass through the reproductive tract. The possible presence of pAKAP4 in sperm precursor cells was studied by immunohistochemistry of boar testis with anti-pAKAP4 antibodies. Signal compatible with pAKAP4 was detected at the cytoplasm of early spermatids (Fig. 5A) and at the flagellum of spermatozoa contained in testis (Fig. 5B), while no signal was seen in the controls. This indicates that AKAP4 is synthesized in early spermatids and localizes at sperm tail (probably as the processed form, p80) and at the periacrosomal region during spermiation.

\section{DMBT1 effect and progesterone-induced acrosomal reaction involve different tyrosine phosphorylation patterns}

We have previously reported that p97/AKAP4 is tyrosine phosphorylated by DMBT1 when boar sperm are incubated in capacitating conditions (Fig. 6, line 3) and that purified DMBT1 (220 kDa) is not phosphorylated under the same conditions (Teijeiro et al. 2008). The acrosomal alteration effect produced by DMBT1 (Teijeiro et al. 2011) is similar to a previously reported partial acrosome reaction pattern detected by chlortetracycline staining in human sperm (Perry et al. 1995). Thus, tyrosine phosphorylation was compared between boar sperm treated with DMBT1 and subjected to acrosome reaction induction with progesterone. Fetuin was used as a protein specificity control. As shown in Fig. 6, both 
A

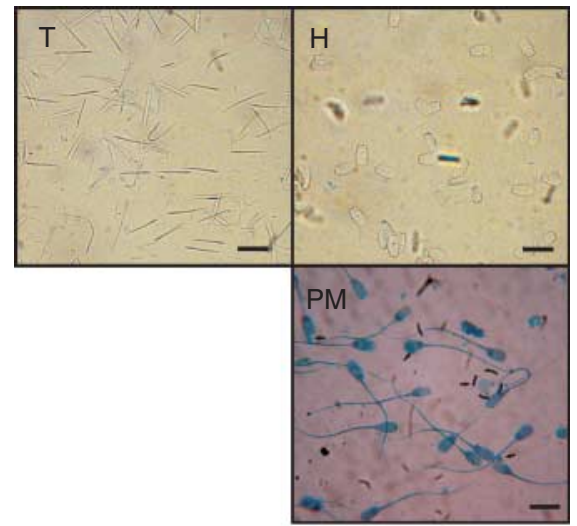

B

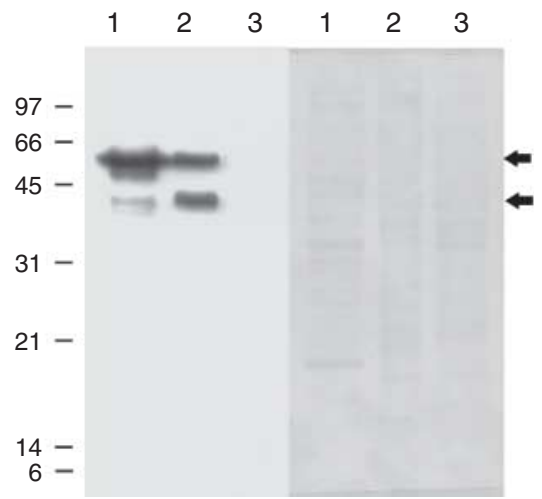

Figure 3 Isolation of sperm heads, tails, and periacrosomal membranes. (A) Microscopic observation of isolated tails $(\mathrm{T})$, heads $(\mathrm{H})$, and periacrosomal membranes before separation from sperm by centrifugation (PM, in circle). (B) Western blot with antiacrosin antibodies and Ponceau red staining of membranes containing $20 \mu \mathrm{g}$ of 1) whole sperm protein extract, 2) acrosomal content, and 3) periacrosomal membrane protein extract. Arrows indicate pro-acrosin and acrosin. Molecular mass standards are indicated in the left side.

DMBT1 (line 3) and progesterone (line 4) produce a decrease in tyrosine-phosphorylated proteins of apparent molecular mass between 38 and $44 \mathrm{kDa}$ when compared with untreated (Fig. 6, line 2) or capacitated (Fig. 6, line 1) sperm. In contrast, the augment of tyrosine phosphorylation of pAKAP4 is noted only after DMBT1 treatment and is not observed in progesterone-promoted acrosome-reacted sperm. Progesterone, instead, promotes the tyrosine phosphorylation of proteins of apparent molecular mass 200 and $220 \mathrm{kDa}$. This indicates that DMBT1's effect proceeds through a different pathway than capacitation and physiological acrosome reaction.

\section{Insights into DMBT1 promoted signal transduction mechanism}

DMBT1 requires the presence of both calcium and bicarbonate in the medium to produce acrosomal alteration on pig-capacitated sperm, and it enhances the tyrosine phosphorylation of AKAP4 under the same conditions (Teijeiro et al. 2008). To analyze whether these compounds are necessary for protein tyrosine phosphorylation, sperm were incubated in the presence of DMBT1 in TALP medium lacking calcium or bicarbonate. As shown in Fig. 7 (lanes 1, 6, and 7), tyrosine phosphorylation of pAKAP4 is enhanced by DMBT1 in the absence of calcium or bicarbonate. The decrease in tyrosine phosphorylation of 38$44 \mathrm{kDa}$ proteins by DMBT1 treatment is also independent of the presence of calcium or bicarbonate (Fig. 7, lanes 6, 7).

In order to establish the possible mediation of cAMP on DMBT1-induced AKAP4 tyrosine phosphorylation, the nonspecific inhibitor of phosphodiesterases 3-isobutyl-1-methylxanthine (IBMX; $2 \mathrm{mM}$ ) or the cAMP analogue dibutyryl-cAMP (dbcAMP; $4 \mathrm{mM}$ ) was added to sperm incubation media, in capacitating conditions, in the presence or absence of DMBT1. As shown in Fig. 7, the phosphorylation pattern induced by DMBT1 was not affected. Controls without DMBT1 show the patterns previously reported for IBMX- and dbAMP-treated capacitating porcine sperm at the same concentrations (Kalab et al. 1998, Tardif et al. 2004).

As the previous result and the report by Teijeiro et al. (2011) suggest that cAMP and protein kinase A (PKA) are probably not related to AKAP4 phosphorylation by DMBT1, the possible involvement of other frequent pathway was analyzed studying protein kinase C (PKC) activation effect on boar sperm. To this aim, PKC activator phorbol-12-myristate-13-acetate (PMA) was used. As, to our knowledge, PKC activation experiments have not been previously reported in boar sperm, we checked its activation and determined the optimal PMA concentration by incubating sperm in capacitating conditions with PMA and detecting PKC activity by western blot with phospho-(S) PKC antibodies raised against the motif $\mathrm{R} / \mathrm{K}-\mathrm{X}-\mathrm{S}^{*}-\mathrm{H} y \mathrm{~d}-\mathrm{R} / \mathrm{K}$, which detect phosphorylated sequences specific of PKC activity. As shown in Fig. 8A, changes in the quantity of PKCphosphorylated proteins are seen from $500 \mathrm{nM}$ of PMA. Thus, PMA was used at higher concentration to assay the possible effect of PKC activation on protein tyrosine phosphorylation and acrosomal status. No effect was noted as to acrosome alteration throughout the experiment (Fig. 8B). As to tyrosine phosphorylation, an increase in some tyrosine-phosphorylated proteins is seen upon capacitation in the presence of PMA (Fig. 8C), being an augment in the tyrosine phosphorylation of an $80 \mathrm{kDa}$ protein noticeable. However, no significant increase in the phosphorylation of p97 was detected, nor was a diminution of the 38-44 kDa group, as occurs upon DMBT1 treatment, indicating that PKC does not mediate DMBT1's effect. 

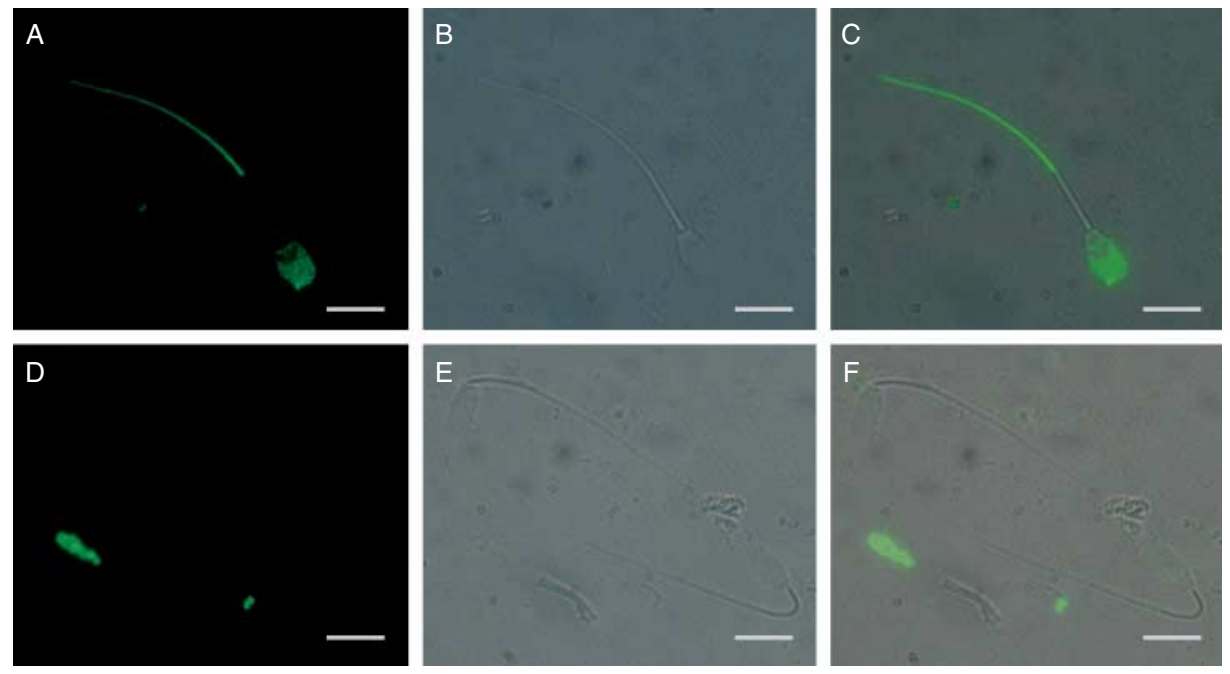

Figure 4 Immunocytochemical localization of pAKAP4 in porcine sperm. Immunocytochemistry with antipAKAP4 (A, B and C) and pre-immune serum (D, E and $F)$. $A$ and $D$,

fluorescence detection; $B$ and $E$, bright field; $C$ and $F$, merge. Barr indicates $10 \mu \mathrm{m}$.

\section{Discussion}

Studying the porcine oviductal cell-sperm interaction, we have previously reported the identification and localization of SBG (Marini \& Cabada 2003, Perez et al. 2006), a glycoprotein that mainly produces three effects on sperm, decrease in motility, acrosome alteration, and tyrosine phosphorylation of a protein of apparent molecular mass $97 \mathrm{kDa}$ (p97; Teijeiro et al. 2008), and proposed a role for it in sperm selection. Further studies allowed us to identify SBG as an oviductal form of DMBT1 (Teijeiro et al. 2012). In this work, we begin to elucidate the mechanism of action of DMBT1 by identifying p97 as porcine AKAP4 by mass spectrometry and immunological methods (Figs 1 and 2). We detected two variants of AKAP4, the $97 \mathrm{kDa}$ form that is tyrosine phosphorylated by DMBT1 treatment present only in periacrosomal membranes (Fig. 2C) and a $\sim 80 \mathrm{kDa}$ reactive protein in periacrosomal membranes and tails of mature sperm. These most probably correspond to porcine pro-AKAP4 and mature AKAP4 forms, as processing of this protein has been shown in mouse rendering two protein bands of similar apparent molecular mass (Brown et al. 2003), and anti-mAKAP4 antibodies provided by Dr Eddy showed the same two protein bands that were shown by anti-pAKAP4.

Because RNA translation does not occur within the flagellum, during spermatogenesis, components of the fibrous sheath and other accessory structures must be transported from the cell body to various sites of assembly within the developing tail (Irons \& Clermont 1982). AKAP4 is an X-linked member of the AKAP family of scaffold proteins that anchor CAMP-dependent protein kinases and plays an essential and conserved role in fibrous sheath assembly during spermatogenesis and flagellar function in spermatozoa (Brown et al. 2003, Moretti et al. 2007, Hu et al. 2009). It is the most abundant protein of the fibrous sheath at least of mouse and human sperm; hence, its presence in porcine sperm could be expected and a similar function could be thought. During spermatogenesis, in mouse and human, AKAP4 is synthesized as a $97 \mathrm{kDa}$ precursor, proAKAP4, which is subsequently cleaved to the mature $82 \mathrm{kDa}$ protein (Turner et al. 1998). The detection of an $\sim 80 \mathrm{kDa}$ AKAP4 form in mature sperm tail (Figs 2C and 3 ) together with the previous report of an AKAP4 EST in porcine testicle and the immunohistochemical detection of AKAP4 in spermatids and sperm flagellum in testicles (Fig. 5) support that, in porcine, AKAP4 has probably the same important role in fibrous sheath assembly during spermiation as previously reported for mouse sperm.

In mature sperm, the processed $\sim 80 \mathrm{kDa}$ as well as $97 \mathrm{kDa}$ AKAP4 are detected in periacrosomal membrane extracts (Fig. 2C). As an immunoreactive protein is detected at the cytoplasm of spermatozoa precursor cells in the presumptive acrosomal region (Fig. 5, arrow heads), it is possible to infer that AKAP4 is synthesized during spermatogenesis instead of being adsorbed during the sperm journey on the male reproductive tract. As DMBT1 binds to the periacrosomal region of sperm (Teijeiro et al. 2008, 2011), the biological role of AKAP4 on periacrosomal membranes may be related to the response of sperm to DMBT1, which results in an increase in tyrosine phosphorylation exclusively of the $97 \mathrm{kDa}$ pro-AKAP4. In human sperm, pro-AKAP4/ AKAP4 are both tyrosine phosphorylated in a subpopulation of sperm incubated in capacitating conditions (Carrera et al. 1996). Similar to human, $97 \mathrm{kDa}$ AKAP4 is phosphorylated in capacitating conditions in bull (Jagan Mohanarao \& Atreja 2011), hamster (Jha \& Shivaji 2002), and rat sperm (Baker et al. 2010). In boar sperm instead, we did not detect tyrosine phosphorylation of neither of the forms upon capacitation, and only pro-AKAP4 is phosphorylated in response to DMBT1 treatment (Figs 6 and 7). The difference between protein 

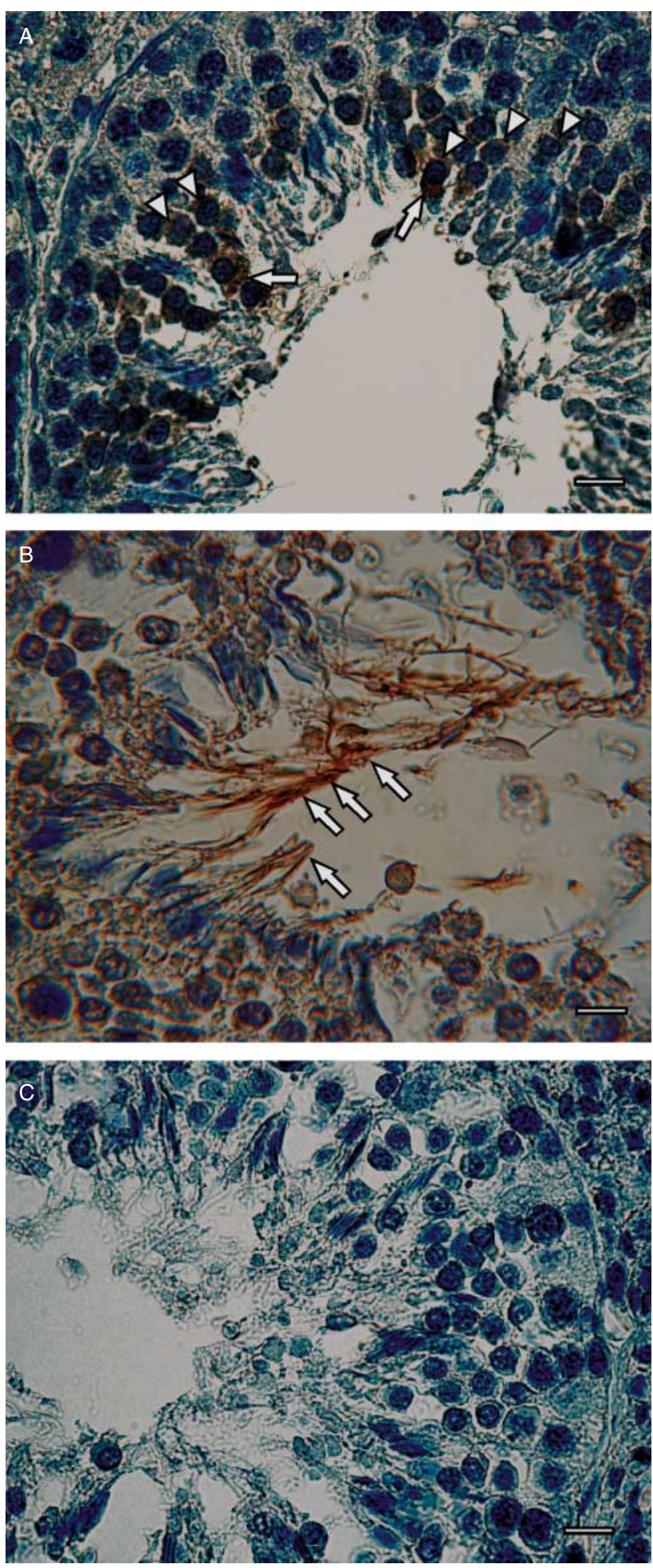

Figure 5 Localization of AKAP4 in porcine testicle. Immunohistochemistry of porcine testicle with (A) and (B) anti-pAKAP4 antibodies, (C) pre-immune serum. Arrows indicate flagellum and presumptive tail-forming regions of the cytoplasm, arrow heads point to presumptive acrosome forming region in spermatid's cytoplasm. Barr indicates $10 \mu \mathrm{m}$. phosphorylation of sperm from different species and the lack of phosphorylation of $97 \mathrm{kDa}$ AKAP4 upon porcine sperm capacitation are in accordance with the previous reports (Tardif et al. 2004).

AKAPs anchor PKA to the fibrous sheath in sperm during spermiogenesis (Visconti et al. 1997) and PKC to postsynaptic densities of neurons (Klauck et al. 1996) between other proteins. Considering this, we explored the possibility of PKA or PKC mediation of AKAP4 phosphorylation by DMBT1 in mature sperm. We previously reported that AKAP4 tyrosine phosphorylation by DMBT1 is not affected by H89, a selective inhibitor of cAMP-dependent PKA (Teijeiro et al. 2011). In this work, the result is corroborated by the use of IBMX and dbcAMP, following the experimental design used by Kalab et al. (1998), indicating that DMBT1's effect over protein tyrosine phosphorylation is independent of the PKA inductor CAMP. PKC activator PMA was used to analyze the possible involvement of PKC (to our knowledge, analyzed for the first time in boar sperm) in the effects produced by DMBT1: AKAP4's tyrosine phosphorylation and acrosome alteration. After determining that this compound affects the phosphorylation pattern of porcine sperm proteins by PKC induction (Fig. 8A), corresponding concentrations of PMA were assayed. Unlike other mammals, in which PKC activation promotes acrosome reaction (Naor \& Breitbart 1997), no effect was noted on porcine acrosome reaction, acrosome alteration, nor phosphorylation of $97 \mathrm{kDa}$ AKAP4 (Fig. 8B and C), indicating that PKC does not probably mediate DMBT1's action. Although an increase in the tyrosine phosphorylation of a $\sim 80 \mathrm{kDa}$ band, which could correspond to processed AKAP4, was observed upon PMA treatment, this protein is not tyrosine phosphorylated by DMBT1 and thus would not be related to the matter of this work. These results show that the main known phosphorylation pathways that involve PKA or PKC, do not mediate DMBT1promoted pro-AKAP4 phosphorylation in pig sperm.

Bicarbonate induction of sperm protein tyrosine phosphorylation has been previously reported (Visconti et al. 1999), but no $97 \mathrm{kDa}$ protein was phosphorylated. Calcium-dependent tyrosine phosphorylation has been demonstrated in pig sperm for p32 (Bailey et al. 2005). Porcine pro-AKAP4 tyrosine phosphorylation promoted by DMBT1, however, does not depend on the presence of any of these compounds (Fig. 7), but the acrosome alteration effect produced by DMBT1 is not seen upon incubation of sperm in the lack of calcium or bicarbonate (Teijeiro et al. 2008). These results indicate that the phosphorylation of AKAP4 is probably an early step in DMBT1's mechanism of action, while posterior changes gated by calcium and bicarbonate are needed to produce acrosomal alteration. Alternatively, acrosome alteration and AKAP4 phosphorylation may form part of two independent processes induced by DMBT1. 


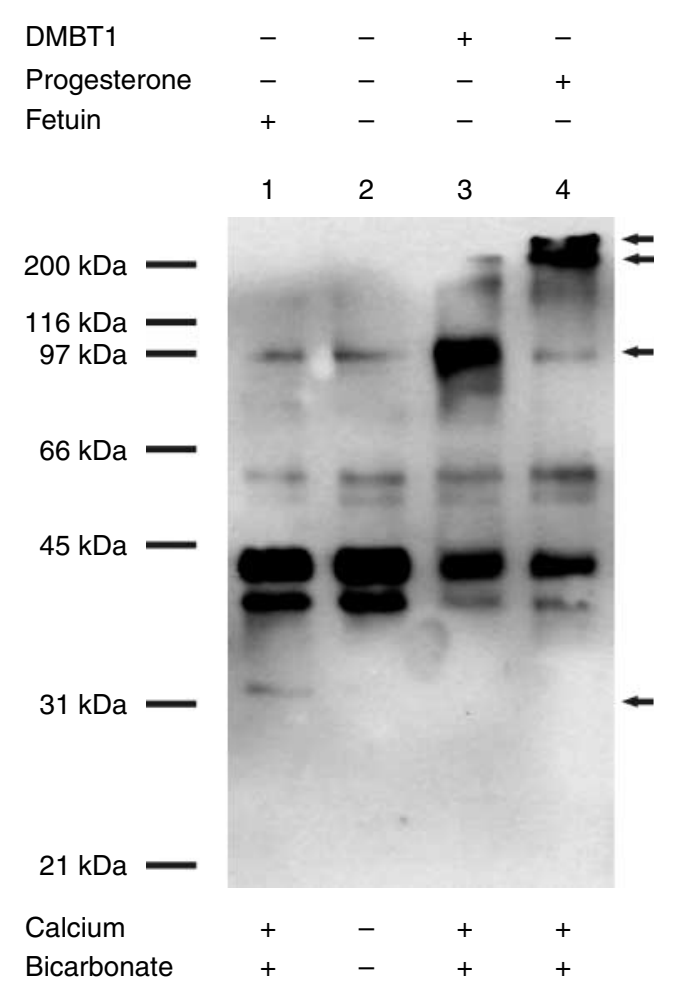

Figure 6 Protein tyrosine phosphorylation pattern of sperm treated with DMBT1 and progesterone. Western blot with antiphosphotyrosine antibodies of sperm incubated in (1) capacitating conditions with fetuin as control glycoprotein, (2) noncapacitating conditions, without calcium and bicarbonate, (3) capacitating conditions in the presence of DMBT1, and (4) capacitating conditions followed by progesterone $(1 \mu \mathrm{g} / \mathrm{ml})$ treatment. Molecular mass standards are indicated in the left side. Arrows indicate proteins of 32, 97, 200 and $220 \mathrm{kDa}$.

Progesterone induces the tyrosine phosphorylation of 94 kDa (Tesarik et al. 1993) and 97 kDa (Bonaccorsi et al. 1995) human sperm proteins. Although similar in molecular weight, it is not known whether these proteins correspond to either human pro-AKAP82 or AKAP82 (actually pro-AKAP4 and AKAP4). In contrast, boar sperm incubated with progesterone show 200 and $220 \mathrm{kDa}$ phosphorylated proteins. Progesterone shares with DMBT1 a dephosphorylation effect over the 38$44 \mathrm{kDa}$ protein group (Fig. 6). The difference in the tyrosine phosphorylation patterns shown upon acrosome reaction provoked by the physiological inducer progesterone (Melendrez et al. 1994) and acrosome alteration produced by DMBT1 indicates that they are different processes that, however, may share a dephosphorylation part of their pathways.

Pro-AKAP4 tyrosine phosphorylation by DMBT1 requires capacitation conditions. The dynamic membrane changes produced by the capacitation process probably produce conformational changes on a protein that directly or indirectly phosphorylates pro-AKAP4 when DMBT1 is present. This assumption, together with the independence of calcium, bicarbonate, PKA, and
PKC, also supports that pro-AKAP4's phosphorylation is an early step of DMBT1 signal transduction pathway that leads to acrosome alteration.

The role of AKAP4 in sperm motility is still unclear; however, absence or decrease in AKAP4 seems to be associated with absent or weak sperm motility (Moretti et al. 2007, Zheng et al. 2010). A relationship between cleavage of pro-AKAP4 or phosphorylation of any of AKAP4 forms and motility has been hypothesized; however, a connection between these molecular processes and an effect on motility has not yet been proven (Stouffs et al. 2009). One of the DMBT1's effects is the decrease of sperm motility. We have hypothesized that a correlation could exist between this effect and p97 phosphorylation. However, DMBT1 induces phosphorylation only of pro-AKAP4, which is present in the periacrosomal region, and not of the processed $\sim 80 \mathrm{kDa}$ form that is present in the flagellum. Also, when boar sperm are treated with DMBT1, tyrosinephosphorylated proteins are detected in the periacrosomal membrane fragments of altered acrosomes instead of the tails (Teijeiro et al. 2011). These observations allow inferring that the process is more related to acrosomal alteration than to flagellum-dependent changes in motility. A similar conclusion has been inferred for human sperm by Luconi et al. (2011).

In whole, we show that porcine sperm contain proAKAP4 and AKAP4. That pro-AKAP4 proteolysis seems

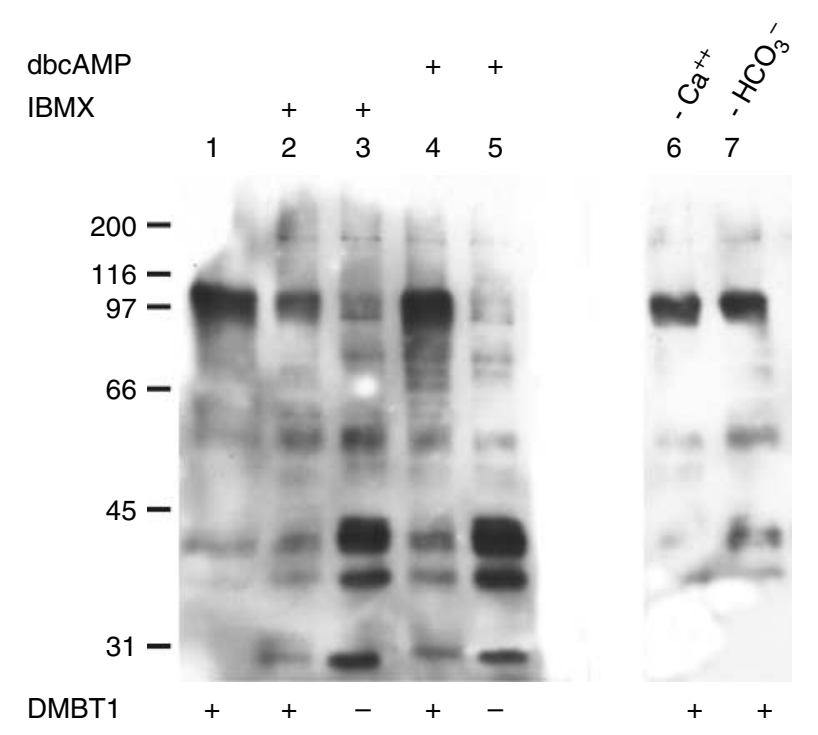

Figure 7 Effect of calcium, bicarbonate, dibutyryl-AMPC, and IBMX on AKAP4 tyrosine phosphorylation by DMBT1. Western blot with antiphosphotyrosine antibodies of sperm treated with (1) DMBT1 in capacitating conditions, (2) DMBT1 and $2 \mathrm{mM} \mathrm{IBMX,} \mathrm{(3)} 2 \mathrm{mM}$ IBMX in the absence of DMBT1, (4) DMBT1 and 4 mM dbcAMP, (5) dbcAMP without DMBT1, (6) DMBT1 treatment in medium lacking calcium, and (7) DMBT1 treatment in medium lacking bicarbonate. DMBT1 was always used at $150 \mu \mathrm{g} / \mathrm{ml}$. Molecular mass standards are indicated in the left side. 


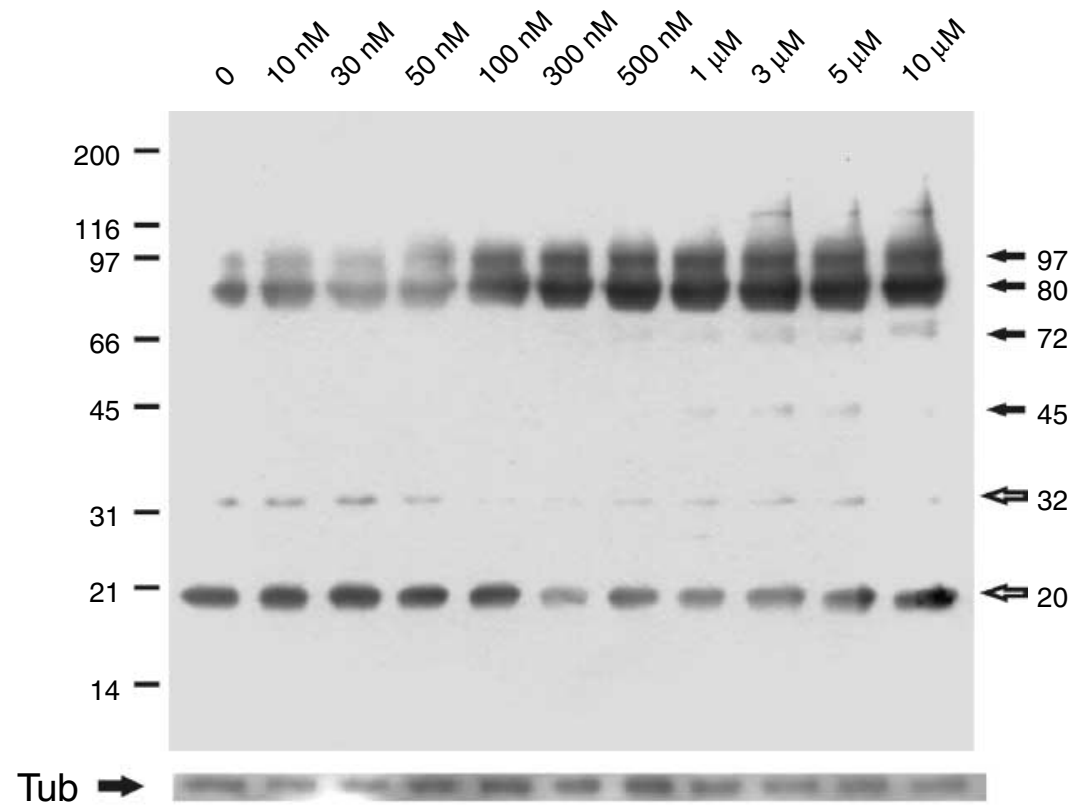

Figure 8 Analysis of PKC activation by PMA in porcine sperm. (A) Western blot with phosphor-(S) PKC substrate polyclonal antibodies of protein extracts from sperm $\left(10^{6}\right)$ treated with the indicated PMA concentrations. Black arrows indicate proteins that suffer an increase in phosphorylation in serine and white arrows indicate proteins that suffer a decrease in serine phosphorylation. (B) Time course detection of the rate of sperm with

B

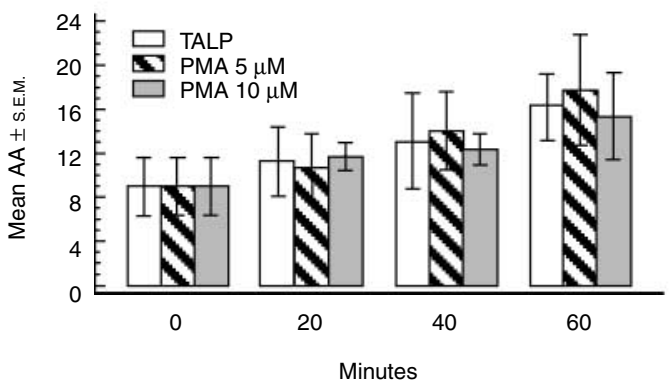

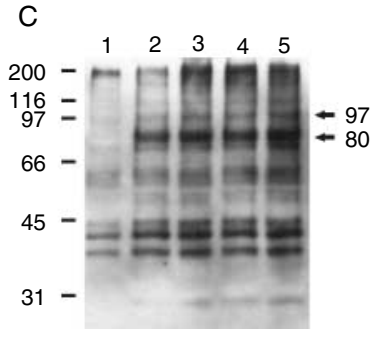
acrosomal alteration upon incubation in capacitating conditions with 0 (open square), $5 \mu \mathrm{M}$ (striked square), and $10 \mu \mathrm{M}$ (grey shaded square) PMA, $n=6(P<0.0001)$. (C) Western blot with antiphosphotyrosine antibodies of sperm $\left(10^{6}\right)$ incubated in capacitating conditions in media containing 0 (lane 1), $500 \mathrm{nM}$ (lane 2), $1 \mu \mathrm{M}$ (lane 3), $5 \mu \mathrm{M}$ (lane 4), and $10 \mu \mathrm{M}$ (lane 5) PMA. Arrows indicate proteins of apparent molecular mass $80 \mathrm{kDa}$, which shows increased tyrosine phosphorylation, and $97 \mathrm{kDa}$. Molecular mass standards are indicated in the left side. to be related to AKAP4 localization at the tail and occurs during spermiation, supporting a role in fibrous sheath assembly. The only known stimulus for porcine sperm AKAP4 tyrosine phosphorylation is the presence of DMBT1 upon capacitation, and it only occurs for the precursor form. Although the possibility that pro-AKAP4 phosphorylation and acrosome alteration are not related cannot be ruled out, the results presented in this work support the hypothesis that DMBT1-promoted proAKAP4 phosphorylation is an early step on the pathway that leads to acrosome alteration.

We have previously proposed that DMBT1 is at least partially responsible for acrosome damage and decrease in motility on sperm that have begun capacitation at the isthmus, as part of a sperm selection mechanism. We refer to this selection as negative in opposition to the positive selection of high-quality sperm that occurs during sperm reservoir formation. The sperm selection assisted by DMBT1 would alter the membrane of sperm that have begun capacitation probably unsynchronized from ovulation, preventing them from reaching the ampulla, and may thus have further consequences on prefertilization polyspermy prevention.

\section{Materials and Methods}

\section{Chemicals}

Unless otherwise stated, chemicals were obtained from SigmaAldrich.

\section{Media}

Sperm-capacitating medium was Tyrode's medium, TALP (Parrish et al. 1988), which contains $96 \mathrm{mM} \mathrm{NaCl}, 3.1 \mathrm{mM}$ $\mathrm{KCl}, 2.0 \mathrm{mM} \mathrm{CaCl}, 0.4 \mathrm{mM} \mathrm{MgSO}, 0.3 \mathrm{mM} \mathrm{NaH}_{2} \mathrm{PO}_{4}$, $20 \mathrm{mM}$ HEPES, $21.6 \mathrm{mM}$ sodium lactate, $1 \mathrm{mM}$ sodium pyruvate, $15 \mathrm{mM} \mathrm{NaHCO}_{3}$, and $5 \mathrm{mM}$ glucose. When indicated, variations were prepared lacking $\mathrm{CaCl}_{2}$ or 
$\mathrm{NaHCO}_{3}$. To avoid acrosome alterations by osmotic shock, the osmolarity of these solutions was maintained at 285315 mOsm with $\mathrm{NaCl}$.

\section{DMBT1 purification}

DMBT1 was purified as reported by Marini \& Cabada (2003). Briefly, the isthmic part of gilt's oviducts was separated and opened longitudinally. Epithelial cells were obtained by scrapping with the blunt side of a scalpel blade, disaggregated, washed, and disrupted in Potter homogenizer. Fractions enriched in plasmatic membrane were prepared by differential centrifugation. Extracts of these fractions were obtained by incubation in $0.5 \mathrm{M} \mathrm{NaCl}, 0.2 \%$ Triton X100, and $10 \mathrm{mM}$ Tris, $\mathrm{pH} 7.5$, during $1 \mathrm{~h}$ at $4{ }^{\circ} \mathrm{C}$. After centrifugation at $105000 \mathrm{~g}$ for $1 \mathrm{~h}$ at $4{ }^{\circ} \mathrm{C}$, the supernatants were dialyzed against TALP and used for affinity chromatography to boar sperm periacrosomal membranes coupled to Sepharose CL 4B (Marini \& Cabada 2003). Elution was achieved with $0.5 \mathrm{M} \mathrm{NaCl}$, and

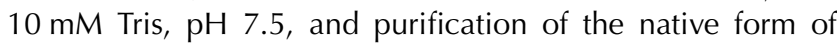
DMBT1 was confirmed by SDS-PAGE on 5-12\% polyacrylamide gradient gels according to Laemmli (1970), followed by silver staining.

\section{Semen collection and treatments}

Semen was collected from adult fertile boars of proven fertility and routinely used for artificial insemination by the glove-hand method. Sperm-rich fraction was diluted in Cronos (Laboratorio Medi Chimica, Reggio Emilia, Italy) and conserved at $16{ }^{\circ} \mathrm{C}$ until use (no more than $24 \mathrm{~h}$ from collection). Quality of the samples was established by evaluating motility, viability, concentration, acrosomal, and morphological parameters (Althouse 1997). Spermatozoa were recovered by centrifugation at $700 \mathrm{~g}$ for $5 \mathrm{~min}$, washed twice in the medium used in each experiment, and resuspended to $10^{7} \mathrm{sperm} / \mathrm{ml}$. For DMBT1 treatment, sperm were incubated in TALP containing $150 \mu \mathrm{g} / \mathrm{ml}$ DMBT1 for $1 \mathrm{~h}$ at $37^{\circ} \mathrm{C}$. In experiments involving dbcAMP, IBMX, or PMA, the indicated agents were included from the beginning of the incubation. For progesterone-promoted acrosome reaction, sperm were capacitated by incubation in TALP at $37{ }^{\circ} \mathrm{C}$ for $1 \mathrm{~h}$, followed by incubation for $15 \mathrm{~min}$ with $1 \mu \mathrm{g} / \mathrm{ml}$ progesterone.

\section{LC-MS/MS analysis and recombinant PAKAP4 expression}

After treatment with DMBT1, sperm were used for SDS-PAGE. A protein band of apparent molecular mass $97 \mathrm{kDa}$ was excised from the gel and a part of it was used for further SDSPAGE with different acrylamide concentration, followed by western blot with antiphosphotyrosine antibodies (in order to confirm that the protein of interest was contained in the sample) and the other one was used for mass spectrometry analysis (LC/MS-MS; Prottech, Inc., Norristown, PA, USA). A porcine pig AKAP4 EST was identified using the peptide sequences obtained from LC-MS/MS analysis (Table 1) for BLAST to the Sus scrofa EST library deposited at the NCBI database (http://www.ncbi.nlm.nih.gov/nucest/84140949). The pig AKAP4 cDNA cloned in pSPORT1 vector was gently gifted by Dr Wen-Chuan Lee and Bobby Gau from the Division of Biotechnology and Animal Resources, Animal Technology Institute Taiwan (ATIT). The corresponding cDNA was subcloned into the BamH1 and EcoR1 sites of the pET-tev expression vector, as His- 6 tag fusion. The new construct was sequenced and the recombinant protein expressed in $E$. coli BL21(DE)3 strain. The His-6-AKAP4 recombinant protein obtained was used to produce polyclonal antibodies in rabbit (Harlow \& Lane 1988).

\section{Immunoprecipitation}

To confirm the identity of AKAP4, immunoprecipitation was developed and the product further subjected to LC-MS/MS. Five hundred microliters of $3 \times 10^{7} \mathrm{sperm} / \mathrm{ml}$ were centrifuged for $5 \mathrm{~min}$ at $700 \mathrm{~g}$ and then the pellet was resuspended in $50 \mu \mathrm{l}$ RIPA buffer (25 mM Tris- $\mathrm{HCl}, \mathrm{pH} 7.6,150 \mathrm{mM} \mathrm{NaCl}, 1 \% \mathrm{NP}-$ 40, $1 \%$ sodium deoxycolate, $0.1 \%$ SDS, $5 \mathrm{mM}$ EDTA, $50 \mathrm{mM}$ dithiothreitol (DTT), and $1 \mathrm{mM}$ phenylmethylsulphonyl fluoride (PMSF)), sonicated $10 \mathrm{~s}$ at $15 \%$ power, gently vortexed, and boiled for $10 \mathrm{~min}$. The suspension was centrifuged $15 \mathrm{~min}$ at $16000 \mathrm{~g}$ and the supernatant recovered and added to $450 \mu \mathrm{l}$ TBS (25 mM Tris- $\mathrm{HCl}, \mathrm{pH} 7.6,150 \mathrm{mM} \mathrm{NaCl}$ ). Then, $15 \mu \mathrm{l}$ anti-AKAP4 antiserum were added and the sample incubated overnight at $4{ }^{\circ} \mathrm{C}$. One hundred microliters of protein $\mathrm{A} / \mathrm{G}$ sepharose (Pierce Biotechnology, Thermo Scientific, Hanover Park, IL, USA) were washed three times with TBS and nonspecific binding sites blocked by $2 \mathrm{~h}$ incubation with $2 \%$ BSA-TBS. After washing with TBS, the resin was incubated with solution containing anti-AKAP4 antiserum for $2 \mathrm{~h}$. Following incubation, the resin was washed five times with TBS and antibodies-AKAP4 complexes were recovered by incubation in $20 \mu \mathrm{l}$ SDS-PAGE loading buffer. Immunoprecipitation products were analyzed by SDS-PAGE and the band of interest was excised from the gel and submitted to a sequencing service. To demonstrate that AKAP4 is tyrosine phosphorylated by DMBT1, a $300 \mu \mathrm{l}$ aliquot of $1 \times 10^{7} \mathrm{sperm} / \mathrm{ml}$ was incubated with $150 \mu \mathrm{g} / \mathrm{ml}$ DMBT1 during $1 \mathrm{~h}$ at $37^{\circ} \mathrm{C}$. Another aliquot was incubated without DMBT1 as control. After incubation, both aliquots were subjected to immunoprecipitation. Immunoprecipitated proteins were resolved in $12.5 \%$ SDSPAGE used for western blot. The membrane was revealed first with antiphosphotyrosine antibodies (pY) and after stripping reprobed with anti-AKAP4 antibodies.

\section{Western blot}

After SDS-PAGE, proteins were transferred to Hybond ECL membranes (GE Healthcare, Rosario, Santa Fe, Argentina). Membranes were blocked with $5 \%$ dry milk in TBS-T (TBS plus $5 \%$ Tween 20) for $1 \mathrm{~h}$ and incubated with the corresponding antibodies. Antiphosphotyrosine MABs (clone 4G10) were supplied by Upstate (Lake Placid, NY, USA) and phosphor-(S) PKC substrate polyclonal antibodies were supplied by Cell Signaling Technology (Beverly, MA, USA; Cat \# 2261). Mouse monoclonal anti-A tubulin antibodies were supplied by Santa Cruz Biotechnology, Inc. (Santa Cruz, CA, USA; Cat sc-8035). 
Polyclonal anti-AKAP4 porcine (anti-pAKAP4) and polyclonal antiacrosin porcine antibodies were obtained by us, using recombinant His-AKAP4 and $38 \mathrm{kDa}$ pig acrosin. Polyclonal anti-AKAP4 that recognized mouse AKAP4 (anti-mAKAP4) was gently provided by Dr Edward Eddy (Laboratory of Reproductive and Developmental Toxicology, National Institute of Environmental Health Sciences, NIH, USA). Secondary antibodies were antirabbit IgG-HRP or antimouse IgG-HRP (Amersham Biosciences) and goat antirabbit Alexa Fluor 488conjugated IgG (Invitrogen). Membranes were incubated with anti-pAKAP4 or anti-acrosin polyclonal antibodies (1:5000) in $3 \%$ dry milk in TBS for $1 \mathrm{~h}$. Anti-m-AKAP4 was used at 1:1000 dilution. For antiphosphotyrosine and antiphospho-(S) PKC substrate $(1: 2000)$, the membranes were incubated overnight at $4{ }^{\circ} \mathrm{C}$. The membranes were washed twice for $15 \mathrm{~min}$ with TBS and incubated with secondary antibodies 1:10 $000 \mathrm{v} / \mathrm{v}$ in TBS during $1 \mathrm{~h}$ at room temperature. After washing, once with TBS and once with TTBS (TBS plus 0.5\% Tween 20), peroxidase activity was revealed using ECL detection with $\mathrm{ECL}$ (Amersham Bioscience) according to the manufacture's instructions.

\section{Immunocytochemistry and immunohistochemistry}

Sperm suspensions were smeared on glass slides optimized for immunohistochemistry (Frosted HiFix ${ }^{\mathrm{NH}}$, TNT, Argentina). Sperm were permeabilized with $100 \%$ methanol at $4{ }^{\circ} \mathrm{C}$ for $30 \mathrm{~min}$. The slides were gently rinsed with TBS twice, blocked with $2 \%$ BSA, $0.2 \%$ Triton X-100 in TBS for $60 \mathrm{~min}$, and then treated with anti-AKAP4 (1:100). After being rinsed twice with TBS, the slides were treated with secondary antibodies at 1:100 for $1 \mathrm{~h}$. After rinsing twice with TBS, the slides were covered with $0.22 \mathrm{M}$ 1,4-diazabicyclo [2,2,2] octane dissolved in glycerol:PBS (9:1) and cover slips. The preparations were examined under a microscope equipped with epifluorescence (BH 2, Olympus Optical Company Ltd., Tokyo, Japan).

Boar testes were obtained from adult fertile animals and tissue sections were processed for immunohistochemistry (García del Moral 1993). In brief, tissue sections were deparaffinized in xylene and then rehydrated through graded dilutions of ethanol $(100,95,70$, and 35\%) followed by two washes in TBS. Antigen retrieval was performed by microwaving slides for $20 \mathrm{~min}$ in $10 \mathrm{mM}$ trisodium citrate $(\mathrm{pH} \mathrm{6)}$. Endogenous peroxidases were inactivated by incubating slides for $15 \mathrm{~min}$ in $3 \% \mathrm{H}_{2} \mathrm{O}_{2}$ in methanol followed by three $5 \mathrm{~min}$ washes in TBS. Sections were blocked with $2 \%$ BSA, $0.2 \%$ Triton X-100 in TBS for $60 \mathrm{~min}$, and then treated with polyclonal anti-AKAP4 antibodies $(1: 100)$ overnight at $4{ }^{\circ} \mathrm{C}$ followed by antirabbit IgG-HRP (diluted 1:100). Bound antibody was visualized by development with 3,3'-diaminobenzidine tetrahydrochloride, stopping the reaction by washing in water.

\section{Cell fractionation}

Boar sperm flagella were isolated by the method of San Agustin \& Witman (1995). Briefly, boar sperm suspended in PBS with $1 \mathrm{mM}$ PMSF were sonicated on ice for $45 \mathrm{~s}$ using a sonicator equipped with a microtip, set at $25 \%$ watt scale. The sonicated sperm suspension was mixed with 2.2 $\mathrm{M}$ sucrose (final sucrose concentration $1.5 \mathrm{M}$ ) and laid on top of a step gradient prepared with $4 \mathrm{ml}$ of $2.2 \mathrm{M}$ sucrose and $4 \mathrm{ml}$ of $2.05 \mathrm{M}$ sucrose. The tubes were centrifuged at $91000 \mathrm{~g}$ (SW40 rotor, Beckman Instruments, Buenos Aires, Argentina) at $4{ }^{\circ} \mathrm{C}$ for $1.5 \mathrm{~h}$. The bottom of the tube contained mostly heads. The sucrose layers were carefully removed to prevent contamination with flagella (1.5-2.05 $\mathrm{M}$ interface) and intact sperm (2.05-2.2 $\mathrm{M}$ interface). The heads and flagella were dispersed with PBS/PMSF and centrifuged at $5000 \mathrm{~g}$ for flagella or $2500 \mathrm{~g}$ for heads. After washing, the pellets were resuspended in $25 \mathrm{mM}$ Tris, $150 \mathrm{mM} \mathrm{NaCl}, 5 \mathrm{mM}$ EDTA, 1\% SDS, $100 \mathrm{mM}$ DTT, and boiled 3 min in bath water. Finally, the extract was centrifuged at $10000 \mathrm{~g}$ at $4{ }^{\circ} \mathrm{C}$ for $5 \mathrm{~min}$ and the supernatants were used for SDS-PAGE.

Periacrosomal membranes were isolated as currently used in our laboratory (Marini \& Cabada 2003, Teijeiro et al. 2008, 2009). In brief, $40 \mathrm{ml}$ of insemination dose were centrifuged at $700 \mathrm{~g} 5 \mathrm{~min}$ at $4{ }^{\circ} \mathrm{C}$, resuspended in $10 \mathrm{mM}$ Tris, $0.1 \mathrm{X}$ Ringer $\left(0.011 \mathrm{M} \mathrm{NaCl}, 0.2 \mathrm{mM} \mathrm{KCl}, 0.14 \mathrm{mM} \mathrm{CaCl}_{2}\right.$, and $10 \mathrm{mM}$ Tris, $\mathrm{pH}$ 7.2), and incubated for $60 \mathrm{~min}$ on ice. An aliquot of this sperm suspension was smeared on microscope slides and stained by Wells-Awa staining (Teijeiro et al. 2008) in order to confirm the loss of acrosomes. Then, the suspension was centrifuged $5 \mathrm{~min}$ at $1000 \mathrm{~g}$ at $4{ }^{\circ} \mathrm{C}$ to pull down the entire sperm and the supernatant was centrifuged again for $5 \mathrm{~min}$ at $1000 \mathrm{~g}$ at $4{ }^{\circ} \mathrm{C}$ to pull down the rest of sperm. The supernatant was centrifuged for $10 \mathrm{~min}$ at $10000 \mathrm{~g}$ at $4{ }^{\circ} \mathrm{C}$ to pellet large cellular debris and then ultracentrifuged $60 \mathrm{~min}$ at $105000 \mathrm{~g}$ at $4{ }^{\circ} \mathrm{C}$. The pellet, containing periacrosomal membranes, was resuspended in $25 \mathrm{mM}$ Tris, $150 \mathrm{mM} \mathrm{NaCl}, 5 \mathrm{mM}$ EDTA, $1 \%$ SDS, and $100 \mathrm{mM}$ DTT and the supernatant containing acrosomal content was dialyzed against water and concentrated by lyophilization.

\section{Acrosomal status analysis}

After treatment of sperm in TALP, at $37^{\circ} \mathrm{C}$ for $1 \mathrm{~h}$ in the presence of the indicated concentrations of PMA, acrosomal status was examined by Wells-Awa staining (Wells \& Awa 1970). Sperm were observed at magnification of $1000 \times$ by bright field microscopy. Acrosome intact sperm were considered to be those having a thickened blue-green region at the apex of the head, a blue-green cap covering the anterior two-thirds of the head, and a pink color in the posterior onethird of the head. Different patterns of acrosome alterations were observed as described previously (Teijeiro et al. 2008), and the rate of sperm with altered acrosomes was estimated as the mean of spermatozoa with any of these alterations or lacking the acrosome. At least 100 spermatozoa were scored in each experiment. Each value represents the mean of three replicates from different boars.

\section{Statistical analysis}

Means of spermatozoa with altered acrosomes were subjected to two-way ANOVA. When F-test results were significant in ANOVA, individual means were further tested by Tukey's multiple range test (Motulsky 1995). 


\section{Declaration of interest}

The authors declare that there is no conflict of interest that could be perceived as prejudicing the impartiality of the research reported.

\section{Funding}

This work was supported by ANPCyT-BID program (grant number PICT 1284) of Argentina.

\section{Acknowledgements}

The authors thank Dr Edward Eddy (National Institute of Environmental Health Sciences, NIH, USA) for anti-mAKAP4 antibodies. They also thank Dr Wen-Chuan Lee and Dr Bobby Gau from Animal Technology Institute Taiwan (ATIT) for the porcine EST clone. Also Frigoríficos Paladini SA for oviduct samples.

\section{References}

Althouse C 1997 Evaluating porcine semen for artificial insemination: standard tests. In Compendium Continuining Education Practicing Veterinarian, 19 Suppl, pp 30-35. Eds Department of Veterinary Clinical Medicine, College of Veterinary Medicine, University of Illinois.

Bailey JL, Tardif S, Dube C, Beaulieu M, Reyes-Moreno C, Lefievre L \& Leclerc P 2005 Use of phosphoproteomics to study tyrosine kinase activity in capacitating boar sperm. Kinase activity and capacitation. Theriogenology 63 599-614. (doi:10.1016/j.theriogenology.2004.09. 034)

Baker MA, Smith ND, Hetherington L, Taubman K, Graham ME, Robinson PJ \& Aitken RJ 2010 Label-free quantitation of phosphopeptide changes during rat sperm capacitation. Journal of Proteome Research $\mathbf{9}$ 718-729. (doi:10.1021/pr900513d)

Bonaccorsi L, Luconi M, Forti G \& Baldi E 1995 Tyrosine kinase inhibition reduces the plateau phase of the calcium increase in response to progesterone in human sperm. FEBS Letters 364 83-86. (doi:10.1016/ 0014-5793(95)00369-K)

Brown PR, Miki K, Harper DB \& Eddy EM 2003 A-kinase anchoring protein 4 binding proteins in the fibrous sheath of the sperm flagellum. Biology of Reproduction 68 2241-2248. (doi:10.1095/biolreprod.102.013466)

Carrera A, Moos J, Ning XP, Gerton GL, Tesarik J, Kopf GS \& Moss SB 1996 Regulation of protein tyrosine phosphorylation in human sperm by a calcium/calmodulin-dependent mechanism: identification of A kinase anchor proteins as major substrates for tyrosine phosphorylation. Developmental Biology 180 284-296. (doi:10.1006/dbio.1996.0301)

Coy P, Lloyd R, Romar R, Satake N, Matas C, Gadea J \& Holt WV 2010 Effects of porcine pre-ovulatory fluid on boar sperm function. Theriogenology $\mathbf{7 4}$ 632-642. (doi:10.1016/j.theriogenology.2010.03. 005)

García del Moral R 1993 Capítulo 2: Fundamentos generales sobre procesamiento histológico de los tejidos. In Laboratorio de anatomía patológica, pp 16-25. Argentina: Interamericana-McGraw Hill.

Harlow E \& Lane D 1988 Immunizing animals. In Antibodies, a Laboratory Manual, pp 92-112. Cold Spring Harbor Laboratory.

Hu Y, Yu H, Pask AJ, O'Brien DA, Shaw G \& Renfree MB 2009 A-kinase anchoring protein 4 has a conserved role in mammalian spermatogenesis. Reproduction 137 645-653. (doi:10.1530/REP-08-0337)

Hunter RH 2002 Vital aspects of fallopian tube physiology in pigs. Reproduction in Domestic Animals 37 186-190. (doi:10.1046/j.14390531.2002.00376.x)

Irons MJ \& Clermont Y 1982 Kinetics of fibrous sheath formation in the rat spermatid. American Journal of Anatomy 165 121-130. (doi:10.1002/ aja.1001650204)
Jagan Mohanarao G \& Atreja SK 2011 Identification of capacitation associated tyrosine phosphoproteins in buffalo (Bubalus bubalis) and cattle spermatozoa. Animal Reproduction Science 123 40-47. (doi:10. 1016/j.anireprosci.2010.11.013)

Jha KN \& Shivaji S 2002 Identification of the major tyrosine phosphorylated protein of capacitated hamster spermatozoa as a homologue of mammalian sperm a kinase anchoring protein. Molecular Reproduction and Development 61 258-270. (doi:10.1002/mrd.1155)

Kalab P, Peknicova J, Geussova G \& Moos J 1998 Regulation of protein tyrosine phosphorylation in boar sperm through a cAMP-dependent pathway. Molecular Reproduction and Development 51 304-314. (doi:10.1002/(SICl)1098-2795(199811)51:3<304::AID-MRD10>3.0. $\mathrm{CO} ; 2-2)$

Klauck TM, Faux MC, Labudda K, Langeberg LK, Jaken S \& Scott JD 1996 Coordination of three signaling enzymes by AKAP79, a mammalian scaffold protein. Science 271 1589-1592. (doi:10.1126/science.271. 5255.1589)

Laemmli UK 1970 Cleavage of structural proteins during the assembly of the head of bacteriophage T4. Nature 227 680-685. (doi:10.1038/ 227680a0)

Luconi M, Cantini G, Baldi E \& Forti G 2011 Role of a-kinase anchoring proteins (AKAPs) in reproduction. Frontiers in Bioscience 16 1315-1330. (doi:10.2741/3791)

Marini PE \& Cabada MO 2003 One step purification and biochemical characterization of a spermatozoa-binding protein from porcine oviductal epithelial cells. Molecular Reproduction and Development 66 383-390. (doi:10.1002/mrd.10361)

Mburu JN, Einarsson S, Lundeheim N \& Rodriguez-Martinez H 1996 Distribution, number and membrane integrity of spermatozoa in the pig oviduct in relation to spontaneous ovulation. Animal Reproduction Science 45 109-121. (doi:10.1016/S0378-4320(96)01566-7)

Mburu JN, Rodriguez-Martinez H \& Einarsson S 1997 Changes in sperm ultrastructure and localisation in the porcine oviduct around ovulation. Animal Reproduction Science 47 137-148. (doi:10.1016/S03784320(96)01631-4)

Melendrez CS, Meizel S \& Berger T 1994 Comparison of the ability of progesterone and heat solubilized porcine zona pellucida to initiate the porcine sperm acrosome reaction in vitro. Molecular Reproduction and Development 39 433-438. (doi:10.1002/mrd.1080390412)

Moretti E, Scapigliati G, Pascarelli NA, Baccetti B \& Collodel G 2007 Localization of AKAP4 and tubulin proteins in sperm with reduced motility. Asian Journal of Andrology 9 641-649. (doi:10.1111/j.17457262.2007.00267.x)

Motulsky H, 2010 Choosing a statistical test. In Intuitive Biostatistics pp 387-389. New York: Oxford University Press.

Naor Z \& Breitbart H 1997 Protein kinase C and mammalian spermatozoa acrosome reaction. Trends in Endocrinology and Metabolism 8 337-342. (doi:10.1016/S1043-2760(97)00134-3)

Overstreet JW \& Cooper GW 1975 Reduced sperm motility in the isthmus of the rabbit oviduct. Nature 258 718-719. (doi:10.1038/258718a0)

Parrish JJ, Susko-Parrish J, Winer MA \& First NL 1988 Capacitation of bovine sperm by heparin. Biology of Reproduction 38 1171-1180. (doi:10.1095/biolreprod38.5.1171)

Perez FA, Roma SM, Cabada MO \& Marini PE 2006 Sperm binding glycoprotein is differentially present surrounding the lumen of isthmus and ampulla of the pig's oviduct. Anatomy and Embryology 211 619-624. (doi:10.1007/s00429-006-0114-0)

Perry RL, Naeeni M, Barratt CL, Warren MA \& Cooke ID 1995 A time course study of capacitation and the acrosome reaction in human spermatozoa using a revised chlortetracycline pattern classification. Fertility and Sterility 64 150-159.

San Agustin JT \& Witman GB 1995 Isolation of ram sperm flagella. Methods in Cell Biology 47 31-36. (doi:10.1016/S0091-679X(08)60787-6)

Satake N, Elliott RM, Watson PF \& Holt WV 2006 Sperm selection and competition in pigs may be mediated by the differential motility activation and suppression of sperm subpopulations within the oviduct. Journal of Experimental Biology 209 1560-1572. (doi:10.1242/jeb. 02136)

Sostaric E, van de Lest CH, Colenbrander B \& Gadella BM 2005 Dynamics of carbohydrate affinities at the cell surface of capacitating bovine sperm cells. Biology of Reproduction 72 346-357. (doi:10.1095/biolreprod. 104.029330) 
Stouffs K, Tournaye H, Liebaers I \& Lissens W 2009 Male infertility and the involvement of the $\mathrm{X}$ chromosome. Human Reproduction Update 15 623-637. (doi:10.1093/humupd/dmp023)

Talevi R \& Gualtieri R 2010 Molecules involved in sperm-oviduct adhesion and release. Theriogenology 73 796-801. (doi:10.1016/j.theriogenology.2009.07.005)

Tardif S, Lefievre L, Gagnon C \& Bailey JL 2004 Implication of cAMP during porcine sperm capacitation and protein tyrosine phosphorylation. Molecular Reproduction and Development 69 428-435. (doi:10.1002/ mrd.20178)

Teijeiro JM, Cabada MO \& Marini PE 2008 Sperm binding glycoprotein (SBG) produces calcium and bicarbonate dependent alteration of acrosome morphology and protein tyrosine phosphorylation on boar sperm. Journal of Cellular Biochemistry 103 1413-1423. (doi:10.1002/ jcb.21524)

Teijeiro JM, Ignotz GG \& Marini PE 2009 Annexin A2 is involved in pig (Sus scrofa) sperm-oviduct interaction. Molecular Reproduction and Development 76 334-341. (doi:10.1002/mrd.20958)

Teijeiro JM, Dapino DD \& Marini PE 2011 Porcine oviduct sperm binding glycoprotein and its deleterious effect on sperm: a mechanism for negative selection of sperm? Biological Research 44 191-199. (doi:10. 4067/S0716-97602011000400003)

Teijeiro JM, Roldán ML \& Marini PE 2012 Molecular identification of the sperm selection involved porcine sperm binding glycoprotein (SBG) as deleted in malignant brain tumors 1 (DMBT1). Biochimie 94 263-267. (doi:10.1016/j.biochi.2011.10.008)

Tesarik J, Moos J \& Mendoza C 1993 Stimulation of protein tyrosine phosphorylation by a progesterone receptor on the cell surface of human sperm. Endocrinology 133 328-335. (doi:10.1210/en.133. $1.328)$
Tienthai P, Johannisson A \& Rodriguez-Martinez H 2004 Sperm capacitation in the porcine oviduct. Animal Reproduction Science $\mathbf{8 0}$ 131-146. (doi:10.1016/S0378-4320(03)00134-9)

Turner RM, Johnson LR, Haig-Ladewig L, Gerton GL \& Moss SB 1998 An X linked gene encodes a major human sperm fibrous sheath protein, hAKAP82, Genomic organization, protein kinase A-RII binding, and distribution of the precursor in the sperm tail. Journal of Biological Chemistry 273 32135-32141. (doi:10.1074/jbc.273.48.32135)

Visconti PE, Johnson LR, Oyaski M, Fornes M, Moss SB, Gerton GL \& Kopf GS 1997 Regulation, localization, and anchoring of protein kinase A subunits during mouse sperm capacitation. Developmental Biology 192 351-363. (doi:10.1006/dbio.1997.8768)

Visconti PE, Stewart-Savage J, Blasco A, Battaglia L, Miranda P, Kopf GS \& Tezon JG 1999 Roles of bicarbonate, CAMP, and protein tyrosine phosphorylation on capacitation and the spontaneous acrosome reaction of hamster sperm. Biology of Reproduction 61 76-84. (doi:10.1095/ biolreprod61.1.76)

Wells ME \& Awa OA 1970 New technique for assessing acrosomal characteristics of spermatozoa. Journal of Dairy Science 53 227-232. (doi:10.3168/jds.S0022-0302(70)86184-7)

Zheng K, Yang F \& Wang PJ 2010 Regulation of male fertility by X-linked genes. Journal of Andrology 31 79-85. (doi:10.2164/jandrol.109. 008193)

Received 24 August 2011

First decision 12 October 2011

Revised manuscript received 8 March 2012

Accepted 27 March 2012 